\title{
Assessment of water scarcity and its impacts on sustainable development in Awash basin, Ethiopia
}

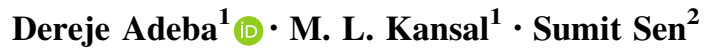

Received: 24 February 2015/ Accepted: 21 April 2015/Published online: 12 May 2015

(C) Springer International Publishing 2015

\begin{abstract}
Equitable access and rational use of water resources is important to cope with water scarcity. The optimal allocation of limited water resources for various purposes is required for sustainable development. Awash river basin is one of the most utilized river basins in Ethiopia. There is increasing demand for water due to recent population growth in the basin because of Urbanization. Excessive water abstraction without properly assessing the available water resources in the basin contributes to water scarcity. The basin exhibits two extreme hydrological events, flooding and drought at different seasons of the year. This paper mainly focuses on surface water resources assessment of the Awash basin, and the temporal gap between water supply and demand. The paper also discusses the impacts of these gaps on sustainable development and suggested few recommendations to minimize it. Using SWAT model, the annual average surface water available is estimated around 4.64 Billion Cubic Meters (BCM) as compared to the estimated demand of about 4.67 BCM in the basin for 1980-2012. This shows that on an average, the demand exceeds the availability by $0.03 \mathrm{BCM}$ during the study period. Seasonal water deficit is even serious. A
\end{abstract}

Dereje Adeba

adeba.dereje@yahoo.com

M. L. Kansal

mitthan@gmail.com

Sumit Sen

sensumit2@gmail.com

1 Department of Water Resources Development and Management, Indian Institute of Technology Roorkee, Roorkee, India

2 Department of Hydrology, Indian Institute of Technology Roorkee, Roorkee 247 667, India detailed seasonal analysis for the last 2 years (2011-2012) shows that the demand exceeds supply by 1.27 and 2.82 BCM during December-April of 2011 and 2012, respectively. However, there is a surplus supply of 1.67 and 3.16 BCM during June-September months of the same year.

Keywords SWAT · Water availability · Water demand . Water balance

\section{Introduction}

Geographically, Ethiopia is located between $3^{\circ}$ to $18^{\circ} \mathrm{N}$ latitude and $33^{\circ}$ to $48^{\circ} \mathrm{E}$ longitude. The total land mass of the country is about 1.13 million square Kilometre, and the current population is estimated at 93 million. Figure 1 shows the location map of Ethiopia in the horn of Africa.

Water resource development is essential to bring about sustainable growth of agriculture, rural development and overall economic progress. Equitable access and sustainable water resources development in a participatory approach of all stakeholders is important to cope with water scarcity. The management and delivery of services in this regard should be to promote the integrated water resources management in a river basin for economic welfare of the people without compromising sustainability of environmental health. The optimal allocation of limited water resources for various purposes is important. There are 12 river basins in Ethiopia. Out of these, two are dry, two are water surplus and eight of them are water deficit basins of different levels. The total runoff from these basins was estimated around 122 BCM per year (Ethiopian River basin master plan studies). There is always some problem related to water in dry and deficit basins which impacted the livelihood of the community and the development 


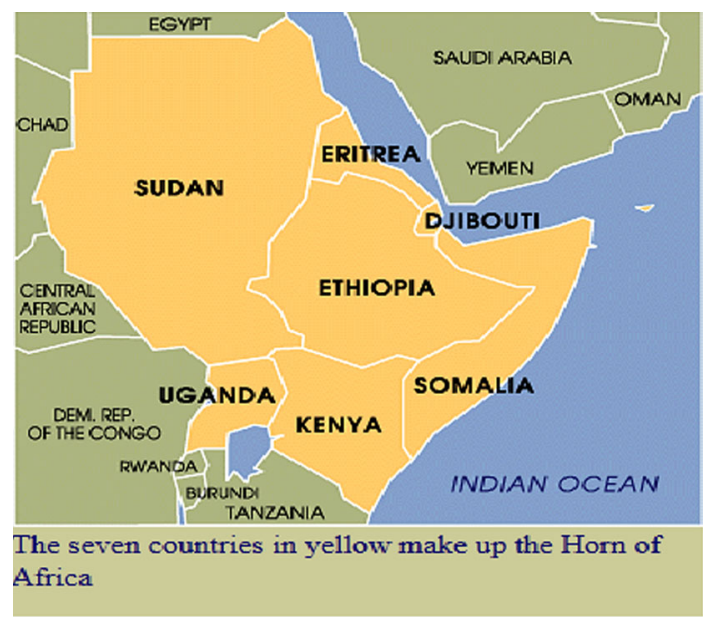

Fig. 1 Location map of Ethiopia

activities. The Awash river basin is one of the river basins of Ethiopia located between $7^{\circ} 53^{\prime} \mathrm{N}$ and $12^{\circ}$ latitude and $37^{\circ} 57^{\prime} \mathrm{E}$ and $43^{\circ} 25^{\prime}$ longitude. It rises at an altitude of about 3000 ma.m.s.l to the west of Addis Ababa, the capital city of the country. Then it flows to the easterly direction and ends at Abbe Lake, the international border of Ethiopia with Djibouti. The river is about $1250-\mathrm{km}$ long. Awash river basin is the most utilized and polluted river basin. The big cities which are located in this basin are dependent on the water of the basin for different purposes. As for water supply, all of Addis Ababa's domestic water sources are reservoirs which are located in rural landscapes of the basin. Water is supplied from three reservoirs (80 \%) and one groundwater system $(20 \%)$ with a total volume of $210,000 \mathrm{~m}^{3} \mathrm{day}^{-1}$ or 0.0767 Billion Cubic Meters (BCM) per year (Van Rooijen and Tadesse 2009). There is an increasing water demand due to recent population growth because of urbanization. On the other hand, there is obvious reduction in water availability in time and space due to both natural and anthropogenic causes. Water is wasted in all sectors, because it is provided by public systems at little or no costs to the users (Kansal et al. 2014). No one in the allocation system shows an interest to conserve water. The price of water is heavily subsidised and does not cover the cost of delivery. The role of water price in water distribution system is that it helps in efficient allocation of existing water supplies. It helps adjust demand to the available supply and in equitable treatment of water users. Effective pricing structure helps achieving in conservation of water by reducing peak demands on the system. Prices charged can also affect quantity of water withdrawn by commercial and industrial users, thereby affecting the volume of water that returns through sanitary sewers for treatment. The real cost of water (development, transport, treatment and delivery) must be reflected in water rates when prices are fixed.
Irrigation potential is very high in the basin. The estimated land area suitable for irrigation is about 205,400 ha, $4.7 \%$ of irrigable area in the country (Taddese et al. 2012). Many of the commercial farms in the country are located along the middle and downstream of the basin, and largescale withdrawals of water in this basin are for irrigation purpose. The nature and water yielding process of every basin are unique, and water abstraction should be done with the basic understanding of the complex nature of the basin. In some of small- and medium-scale irrigation projects, water is available to users at no cost or at a heavily subsidised price. The current situation of the basin therefore reflects a water crisis by the general mismanagement and over exploitation of water resources. Irrigation efficiency is low and it is time to introduce current technologies, such as drip, sprinkler and canal irrigations which can save water without decreasing productivity of the system. Implementation of such technologies will enhance the potential of the Awash river to sustainably serve the basin communities.

Policies should be designed to avoid mismanagement and overuse of water in different sectors. Strict rationing is often required to allocate the resulting scarcity so that a large share of water to meet demand must come from water saved from different uses through water policy reform. Demand management can bring about physical savings of water by improving the efficiency of water use especially in agriculture (FAO 2012). Efficiency in water use should also improve in urban and industrial uses. Supply management can be another option to address the problem of water scarcity in the basin.

Water pollution in the basin is another basic problem which aggravates water shortage. The industries in the major cities of Ethiopia located in the basin are the sources of water pollution. Urbanization, industrial development agricultural chemicals and fertilizers overcharged the carrying capacity of water bodies and resulted in deterioration of surface water quality and groundwater aquifer in the basin. Pollutants such as toxic metals from the tanneries are the main sources of pollution. Sugarcane base industry is another source of pollution to the basin due to large quantity of wastewater having high pollutant concentration. These effluents discharged into the river either without treatment or with minimum treatment. This issue requires an urgent attention from the government and stakeholders. Water logging and salinization are putting increasing pressure on land and water quality in the basin in irrigated agriculture.

Through collection and analysis of reliable and adequate data on water resource status, sound decisions can be made on how best to develop and manage these resources. Proper assessment of the water resources in time and space is important to plan future water use rationally and on a sustainable basis. The assessment of the availability of water in the basin and priority setting of its use is important 
before planning for the expansion and development of additional sectors which poses pressure on water availability. Therefore, the main objectives of this study are to (1) assess the total surface water availability, water demand and the gap between supply and demand in the basin and (2) recommend different options to minimize the gap between supply and demand.

\section{Methodology}

In order to achieve the above objectives, the methodology followed in this study includes the assessment of water resources availability and water demand.

\section{Assessment of water resources availability}

Water resources availability was estimated using Soil and Water Assessment Tool (SWAT) model. SWAT is a physically based continuous-time, long-term simulation, lumped parameter deterministic model developed by United States Department of Agriculture-Agricultural Research Service (USDA-ARS), Arnold and Fohrer (2005); (Gassman et al. 2007). It is not designed to simulate detailed, single-event flood routing (Neitsh et al. 2002). It operates on a daily and hourly time steps. The model is computationally efficient and it uses physically based inputs like weather variables, soil properties, topography, vegetation and land management (Singh et al. 2013). The basin boundary and the drainage pattern of the basin are delineated by ArcGIS10.1 with a 90-m-resolution digital elevation model.

The conceptual framework of the model developed in this research shows the database types and its linkage to different points in the process of SWAT model. The spatial and hydrometeorological data were used for initial setup of the Model (Fig. 2). The climatic data used by the model can be a measured data or it can be generated by the model using inbuilt weather generator. However, for this study, only measured data were used. The location tables of different weather data were loaded and linked to the files created for this purpose to write input tables by the model. During the writing-up process of input tables, additional data like Manning's roughness coefficient for overland flow, soil data, hydrologic data and management inputs were set up for simulation of the model. When Penman-Monteith or Priestly-Taylor (Monteith 1965) evapo-transpiration routines are used, the SWAT model requires relative humidity, solar radiation and wind speed as an input data (Gassman et al. 2007). In case the Green-Ampts infiltration method is used, the measured or generated sub-daily precipitation inputs are required as the input to the model (Gassman et al. 2007). The maximum and minimum temperature inputs are used in the calculation of daily soil and water temperature (Gassman et al. 2007). Finally, the model was set up to simulate the various hydrological components of the basin.

Though, three options exist in SWAT for estimating surface runoff from HRUs, and the USDA Natural Resources Conservation Service (NRCS) curve number (CN) method is used to estimate surface runoff in this study.
Fig. 2 Conceptual framework of SWAT model and its set up

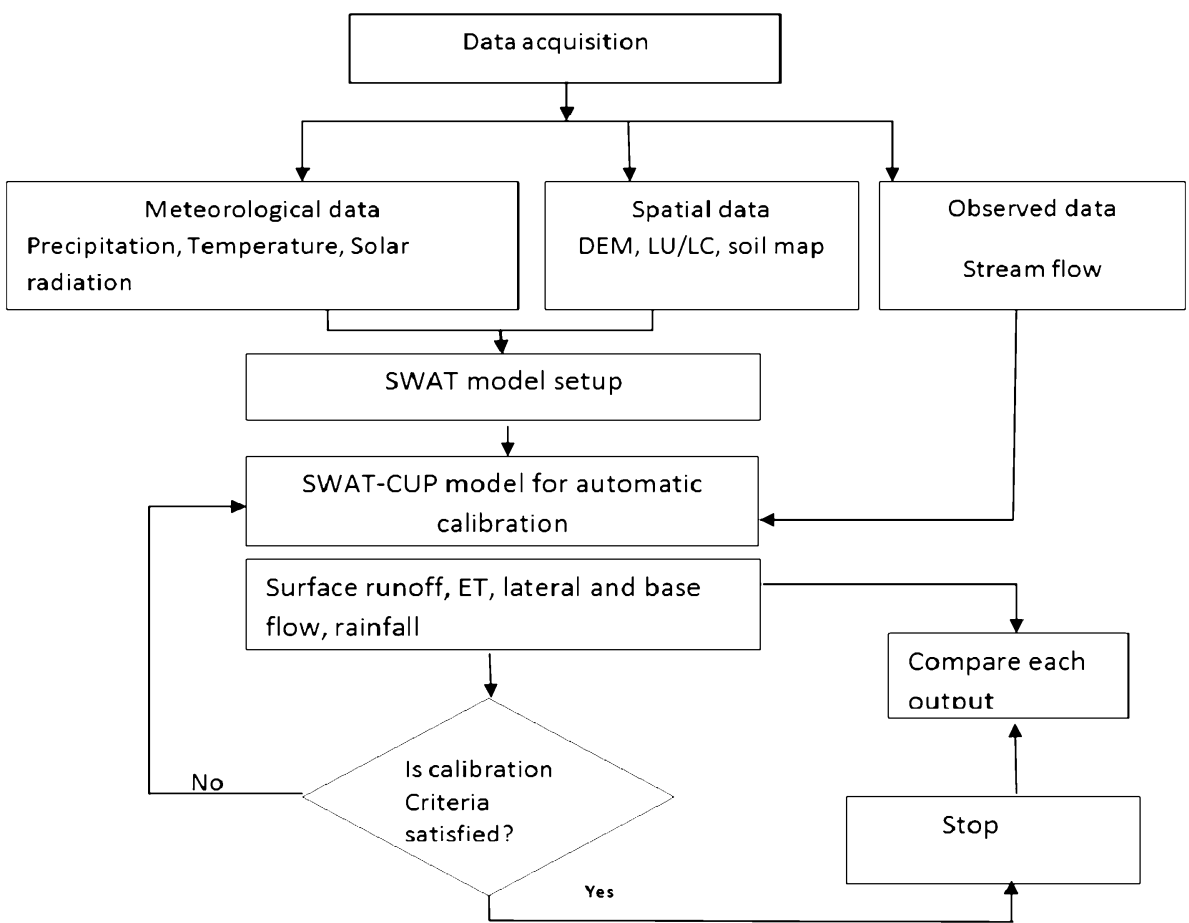


Soil and Water Assessment Tool estimates surface runoff using SCS-CN method,

$Q=\frac{\left(P-I_{\mathrm{a}}\right)^{2}}{\left(P-I_{\mathrm{a}}\right)+S}$

where $Q=$ runoff depth in $\mathrm{mm}, P=$ effective rainfall in $\mathrm{mm}, I_{\mathrm{a}}=$ Initial abstraction in $\mathrm{mm}$ and $S=$ potential maximum retention. But, the initial abstraction, $I_{\mathrm{a}}$ is the function of potential maximum retention $S$. Therefore,

$I_{\mathrm{a}}=\lambda S$

where $\lambda=0.2$ Therefore,

$I_{\mathrm{a}}=0.2 S$

Substituting Eq. 2 in 1 we have,

$Q=\frac{(P-0.2 S)^{2}}{(P+0.8 S)}$

Runoff occurs when $P$ is greater than $0.2 \mathrm{~S}$. The potential retention parameter varies based on type of soil, land use management and slope of the watershed. The potential maximum retention $S$ is related to the dimensionless parameter $\mathrm{CN}$ by the following relation:

$S=\left(\frac{25400}{\mathrm{CN}}\right)-254$

where $\mathrm{CN}=$ curve number.

The output of SWAT model includes surface runoff, evapo-transpiration, stream flow, interception storage, infiltration, reservoir water balance and shallow and deep aquifer that have been developed and validated. The interest of this study is only the surface water availability of the basin. So the outflow of the basin from each subbasin is added to get the total surface water availability.

The uncertainty of parameters such as measured data uncertainty, model uncertainty and parameter uncertainty was checked by using sequential uncertainty fitting (SUFI2). The goodness of fit and the degree to which the calibrated model accounts for the uncertainties are assessed by running $p$-factor and $r$-factors test which were explained in the 'sensitivity analysis' section.

\section{Water demand assessment}

In Awash basin, satisfying water demand for agricultural production is an integral part of food self sufficiency and employment opportunity for the community living in the basin, because agriculture is the foundation of the economy and it employs more than $80 \%$ of the rural population in the country. To calculate the water balance of the basin, the demand of water for different uses is required. To know the demand, it is necessary to assess the human population, livestock population, irrigation activities in the basin and industrial firms available in the basin. After calculating the demands of water for each sector including environmental water requirement, it is added together to arrive at the total water demand and then it is subtracted from the availability of water in the basin to get the balance.

\section{Model performance evaluation criteria}

The accuracy of SWAT simulation results is determined by examination of the coefficient of determination $\left(R^{2}\right)$, the Nash and Sutcliffe (1970) model efficiency coefficient (NSE), the root mean square error (RMSE), percentage bias (PBAIS) and observation standard deviation ratio (RSR). The $R^{2}$ value is an indicator of the strength of the linear relationship between the observed and simulated values, while the (NSE) simulation coefficient indicates how well the plot of observed versus simulated values fits the $1: 1$ line. The $R^{2}$ statistic is calculated as

$R^{2}=\left[\frac{\sum_{i=1}^{n}\left(O_{i}-O_{\mathrm{avr}}\right)\left(P i-P_{\mathrm{avr}}\right)}{\left[\sum_{i=1}^{n}\left(O_{I}-O_{\mathrm{avr}}\right)^{2} \sum_{i=1}^{n}\left(p_{i}-P_{\mathrm{avr}}\right)^{2}\right]}\right]^{2}$

where $R^{2}=$ Coefficient of determination, $O_{i}=$ Observed (measured) value and $P_{i}=$ Modelled (predicted) value.

The SWAT model is further calibrated monthly using the NSE, which is given as,

$\mathrm{NSE}=1-\frac{\sum_{I=1}^{n}\left(O_{i}-P_{i}\right)^{2}}{\sum_{i=1}^{n}\left(O_{i}-O_{\mathrm{avr}}\right)^{2}}$

The root mean square error and mean absolute error are well-accepted absolute error goodness-of-fit indicators that describe differences in observed and predicted values (Legates and McCabe 1999). It is calculated using the relation,

$\mathrm{RMSE}=\sqrt{N^{-1} \sum_{I=1}^{N}\left(O_{i}-p_{i}\right)^{2}}$

Percent bias (PBIAS) measures the average tendency of the simulated data to be larger or smaller than their observed counterparts (Gupta et al. 1999). The optimal value of PBIAS is 0.0 , with low magnitude values indicating accurate model simulation (Moriasi et al. 2007). Positive values indicate model underestimation bias, and negative values indicate model overestimation bias (Gupta et al. 1999). 
PBIAS is calculated by

PBIAS $=\left[\frac{\sum_{I=1}^{n}\left(Y_{i}^{\mathrm{obs}}-Y_{i}^{\mathrm{sim}}\right) \times(100)}{\sum_{1=1}^{n} Y_{i}^{\mathrm{obs}}}\right]$

Observation standard deviation ratio (RSR) standardizes RMSE using the observations standard deviations and it combines both an error index and the additional information recommended by (Legates and McCabe 1999). RSR is calculated as the ratio of the RMSE and standard deviation of measured data, as given:

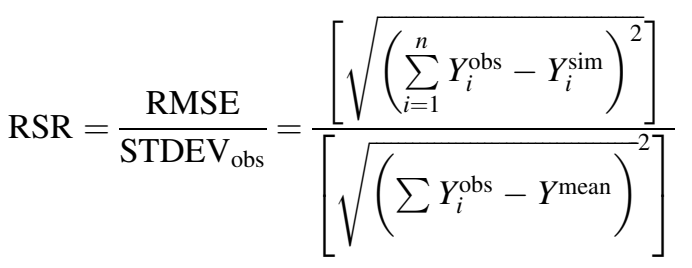

\section{Data requirement and availability}

Assessment of a basin water balance is vital to understand the processes of hydrologic cycle. For this purpose, data collection and field trip for ground truthing, and data verification were used to identify the key features of the basin. The hydrological and meteorological data from 1980 to 2012 were supplied by the Ministry of Water Resources (MoWR) and National Meteorological Service Agency (NMSA) of the government of Ethiopia, respectively. Quality of meteorological data was checked by comparing graphs and double mass curve analysis. The missing data were filled using regression method (Hassan and Croke 2013). River basin master plan study document of the Awash river is consulted, Water Works Design and Supervision Enterprise (WWDSE)/WAPCOS (2005). Information on water abstraction for different purposes was also gathered from different sources, such as water allocation study of the upper Awash valley for existing and future demands (Berhanu 2008; Yibeltal et al. 2013).

Digital elevation models (DEMs) are used to identify stream networks and the land slopes that contribute flow to the water bodies. Modelling of the hydrologic responses over a watershed requires use of soil map and land use/land cover map to provide information on soil types and their hydrologic properties.

The soil physical properties like soil texture, available water content, hydraulic conductivity, bulk density and organic matter content for different layer were processed using Soil-Plant-Air-Water (SPAW) software developed by United States Department of Agriculture (Table 1). The land use of the basin is analysed to check for a significant land use change for the period of 2008-2012. However, there was no significant change during this period, and thus, 2012 land use data were used.

\section{Study area description}

Awash basin covers the total land mass of $110,000 \mathrm{~km}^{2}$ out of which $64,000 \mathrm{~km}^{2}$ is categorized as western basin and contributes almost the entire surface flow of the basin. Other

Table 1 Physical properties of soil in the basin

\begin{tabular}{|c|c|c|c|c|c|c|c|c|c|}
\hline \multirow[t]{2}{*}{ No. } & \multirow[t]{2}{*}{ Soil name } & \multirow{2}{*}{$\begin{array}{l}\text { Hydraulic conductivity } \\
(\mathrm{mm} / \mathrm{h})\end{array}$} & \multicolumn{3}{|c|}{ Textural composition (\%) } & \multirow{2}{*}{$\begin{array}{l}\text { Soil BD } \\
(\mathrm{g} / \mathrm{cc})\end{array}$} & \multirow{2}{*}{$\begin{array}{l}\text { Soil AWC } \\
(\mathrm{cm} / \mathrm{cm})\end{array}$} & \multirow[t]{2}{*}{ Area in $\mathrm{km}^{2}$} & \multirow{2}{*}{$\begin{array}{l}\text { Watershed } \\
\text { area in }(\%)\end{array}$} \\
\hline & & & Sand & Silt & Clay & & & & \\
\hline 1 & Eutric C. & 18 & 22 & 44 & 34 & 0.18 & 1.44 & 2792.9 & 4.41 \\
\hline 2 & Leptosols & 0 & 40 & 10 & 50 & 0.12 & 1.34 & 304.0 & 0.12 \\
\hline 3 & Orthic $\mathrm{S}$ & 38 & 30 & 45 & 25 & 0.11 & 1.45 & 3802.9 & 6.00 \\
\hline 4 & Haplic X. & 20 & 44 & 41 & 15 & 0.15 & 1.43 & 1184.4 & 1.87 \\
\hline 5 & Calcaric F. & 15 & 40 & 40 & 20 & 0.15 & 1.43 & 5480.7 & 8.65 \\
\hline 6 & Dystric N. & 2 & 38 & 32 & 30 & 0.21 & 1.39 & 8280.4 & 13.00 \\
\hline 7 & Eutric R. & 110 & 47 & 45 & 8 & 0.10 & 1.51 & 526.6 & 0.83 \\
\hline 8 & Vertic C. & 6 & 55 & 30 & 15 & 0.11 & 1.47 & $14,704.5$ & 23.2 \\
\hline 9 & Chromic L. & 2 & 32 & 24 & 44 & 0.11 & 1.5 & 4.9 & 0.01 \\
\hline 10 & Eutric F. & 29 & 70 & 13 & 17 & 0.08 & 1.5 & 65.3 & 0.10 \\
\hline 11 & Cambic A. & 117 & 78 & 7 & 15 & 0.04 & 1.42 & 2660.5 & 4.20 \\
\hline 12 & Pellic.V & 1 & 62 & 12 & 24 & 0.24 & 1.39 & 4878.6 & 7.70 \\
\hline 13 & Gypsic Y. & 750 & 12 & 16 & 64 & 0.07 & 1.41 & 45.6 & 0.07 \\
\hline 14 & Eutric N. & 72 & 22 & 14 & 64 & 0.08 & 1.45 & 381.6 & 0.60 \\
\hline 15 & Mollic A. & 91 & 65 & 26 & 9 & 0.15 & 1.43 & $13,335.3$ & 20.36 \\
\hline 16 & Luvic P. & 307 & 34 & 55 & 11 & 0.15 & 1.31 & 231.5 & 0.37 \\
\hline 17 & Haplic C. & 15 & 34 & 57 & 9 & 0.20 & 1.39 & 5320.3 & 8.39 \\
\hline
\end{tabular}


Fig. 3 Location map of Awash basin

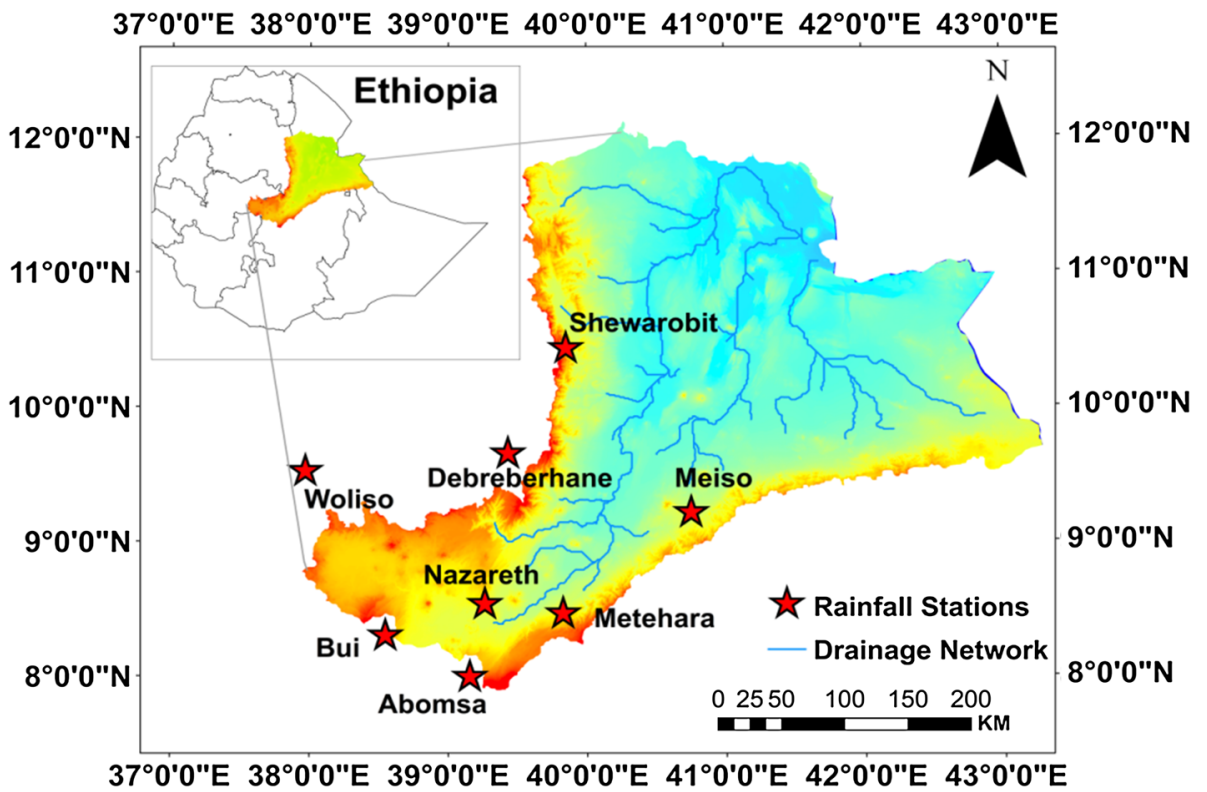

$46,000 \mathrm{~km}^{2}$ area comes under the eastern part which does not contribute any surface flow to the river (MoWR 2014). The elevation of the basin ranges between $250 \mathrm{~m}$ at the Abbe Lake, where the river ends and 4195 ma.m.s.l at the headwater of the river (Fig. 3). The basin is divided into upper, middle and lower Awash. The annual rainfall of the basin varies from about $160 \mathrm{~mm}$ at the northern limit of the basin to $1600 \mathrm{~mm}$ in the western highlands. The mean annual rainfall of the basin is about $895 \mathrm{~mm}$. Mean annual temperature ranges from $9.9{ }^{\circ} \mathrm{C}$ at the North West to $30.5{ }^{\circ} \mathrm{C}$ at the north east of the basin. During the simulation period (1980-2012), the lowest and the highest temperatures recorded in the basin were 0 and $36^{\circ} \mathrm{C}$, respectively at different locations. The rainfall and the maximum and minimum temperatures of the basin at different stations are shown in (Fig. 4). The average wind speed during the same period was $2.7 \mathrm{~m} / \mathrm{s}$ and the maximum value recorded was $9.9 \mathrm{~m} / \mathrm{sec}$, while the average relative humidity was $55.35 \%$. The physical properties of soil control the movement of water through its profile and impacts on the cycling of water within HRU. Based on physical properties, soil of the basin was classified into 17 different classes and indicated in (Fig. 5) below. Slope of the basin is manually divided into three classes (Table 2).

Agriculture is the dominant land use in the basin followed by grassland and shrub land with 51.39, 29.79 and $8.11 \%$, respectively, as shown in (Fig. 6).

Rainfall, Maximum and Minimum temperature data of the basin for the last 33 years (1980-2012) are shown in the following figure.

\section{Results and discussion}

\section{Sensitivity analysis}

Sensitivity analysis is one of the necessary phases in model calibration and preparation for use. It is used to determine the way the results are changing based on change of model parameters. Sensitivity analysis was conducted to identify the sensitive parameters affecting stream flow for subsequent application in stream flow calibration (Kannan et al. 2007). It was carried out using those parameters provided in the SWAT literature (Table 3). The values of the parameters used for sensitivity analysis were within the range suggested in SWAT user's manual and literature (Neitsh et al. 2001).

$p$-factor is used to quantify the degree to which all uncertainties are accounted for and it is the percentage of measured data bracketed by the $95 \%$ prediction uncertainty, (Abbaspour 2012) while $r$-factor quantifies the strength of calibration/uncertainty analysis i.e. $r$ factor is the average thickness of the 95ppu band divided by the standard deviation of the measured data. The value of $p$-factor ranges from 0 to $100 \%$ while that of $r$-factor ranges between 0 and infinity. A $p$ factor of 1 and $r$-factor of 0 is a simulation that exactly corresponds to the measured data. The degree to which the simulated value deviates from these values of $p$ and $r$ can be used to judge the strength of model calibration. 


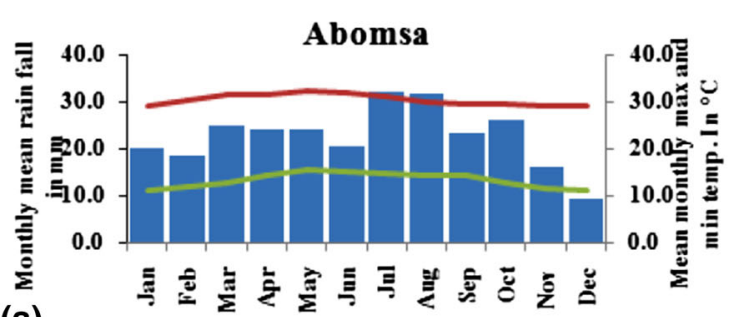

(a)

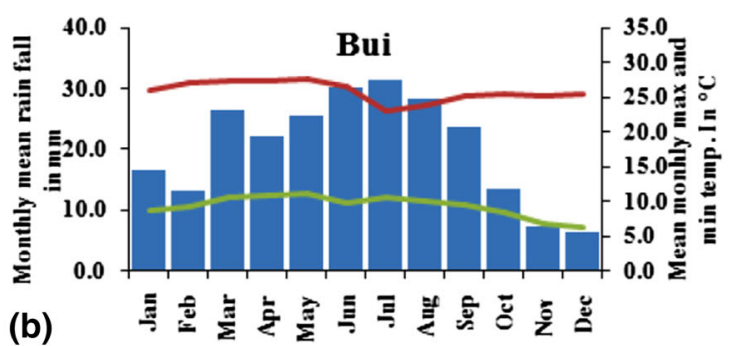

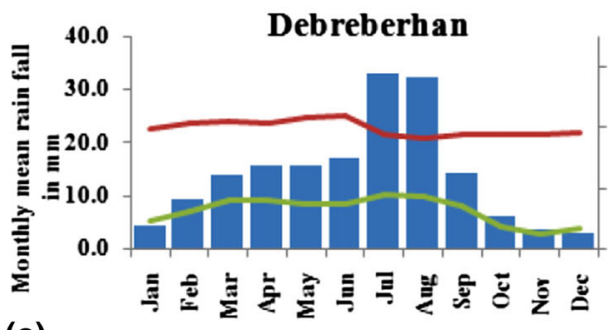

(c)

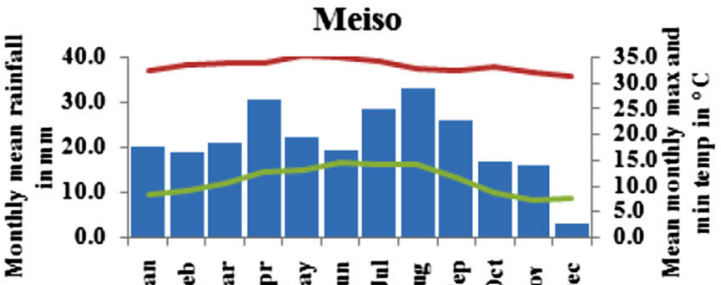

(e)

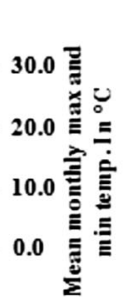

(d)

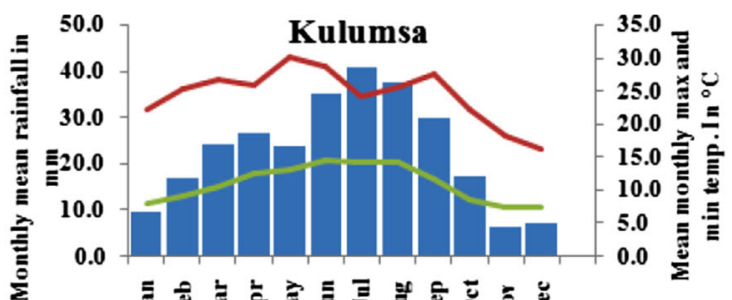

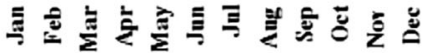

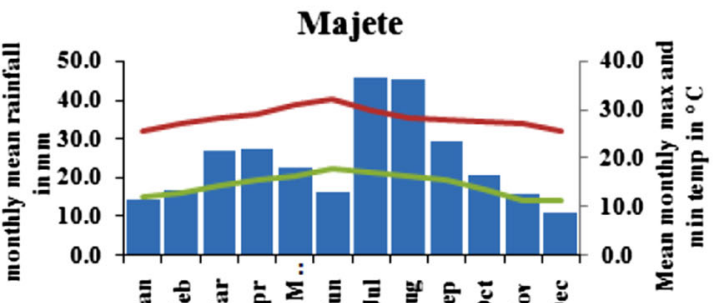

(f)

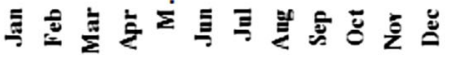

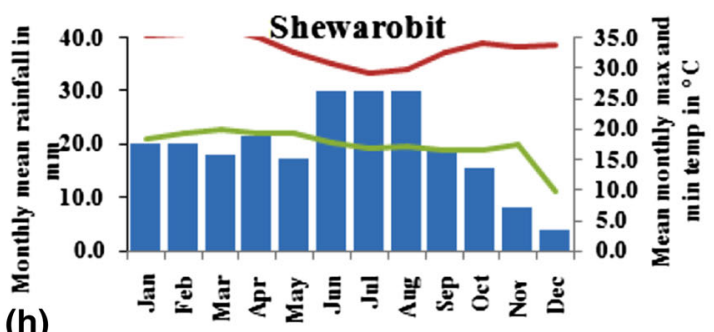

(h)

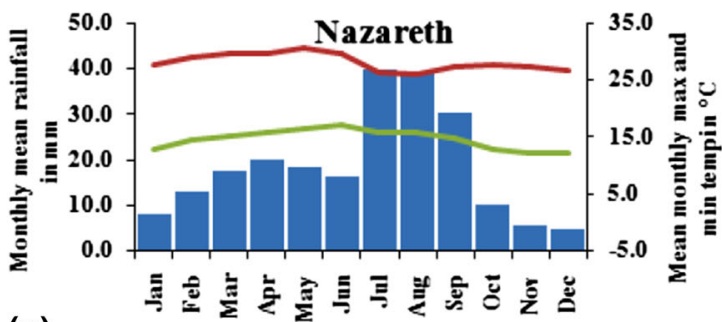

(g) (i)

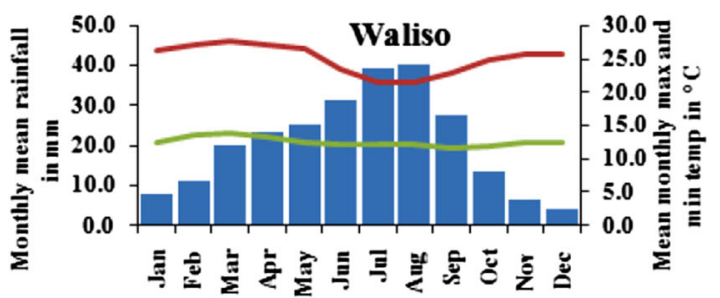

\section{Maximum temperature}

\section{Minimum temperature}

Fig. 4 Long-term weather data of Awash basin at different stations

\section{Model calibration and validation}

Models approximate the reality of the natural systems. Both graphical methods and statistical tests are used in model calibration and validation. The details of simulation of the basin are given in Table 4. The model on the first level is manually calibrated because this is performed only once in the initial calibration phase (Milivojevic et al. 2009). Manual calibration supported by semi-automatic calibration using SUFI2 (Sequential Uncertainty Fitting 2) was used for model calibration and validation. The model has been calibrated and validated using 
Fig. 5 Soil map of Awash basin

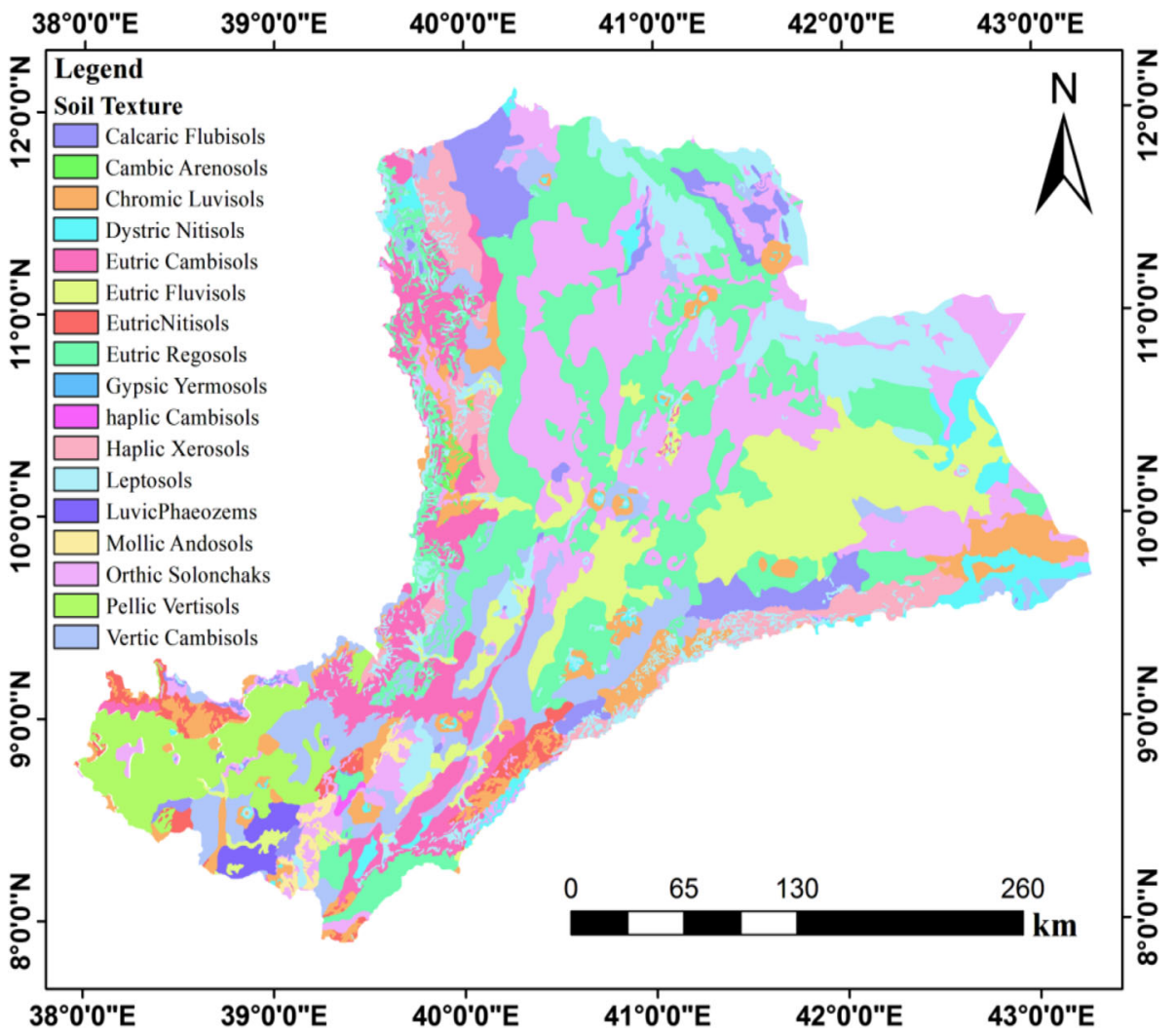

Table 2 a Land use categories in the basin. $\mathbf{b}$ Slope classes of the basin

\begin{tabular}{|c|c|c|c|c|}
\hline \multirow[t]{2}{*}{ S. No. } & \multicolumn{4}{|l|}{ Land use } \\
\hline & Category & Class & Area $\left(\mathrm{km}^{2}\right)$ & Watershed area $(\%)$ \\
\hline \multicolumn{5}{|l|}{$\mathbf{a}$} \\
\hline 1 & Agricultural land close grown & AGRC & $33,058.92$ & 51.65 \\
\hline 2 & Meadow Bromegrass & BROM & $19,087.44$ & 29.82 \\
\hline 3 & Range brush & RNG B & 5190.09 & 8.11 \\
\hline 4 & Forest mixed & FRST & 4884.35 & 7.63 \\
\hline 5 & Water body & WATR & 499.20 & 0.75 \\
\hline 6 & Residential & URBN & 1280.00 & 2.00 \\
\hline S. No. & Slope class & & Area $\left(\mathrm{km}^{2}\right)$ & Area $(\%)$ \\
\hline \multicolumn{5}{|l|}{ b } \\
\hline 1 & $0-25$ & & $58,736.64$ & 91.78 \\
\hline 2 & $25-45$ & & 2253.99 & 3.52 \\
\hline 3 & $\geq 45$ & & 3009.37 & 4.70 \\
\hline
\end{tabular}

observed stream flow time series for six gauging stations (Table 5). The result shows a good model performance for the basin (Fig. 7). During the calibration period (1980-1999), the Nash-Sutcliffe efficiency (NSE) for monthly flow simulations varied between 0.75 and 0.90 , while the $R^{2}$ value for the same period of calibration varied between 0.78 and 0.92 . But during the validation period (2000-2012), NSE values range from 0.55 to 0.93 , while the value of $R^{2}$ ranges from 0.57 to 0.95 for the basin.

\section{Model calibration parameters}

AWC, CN2, APHA_BF, GW_DELAY, REVAP_MN, etc. are some of the parameters used for calibration (Table 6). An increase in AWC will decrease surface runoff and base 
Fig. 6 Land use map and slope classes of Awash basin

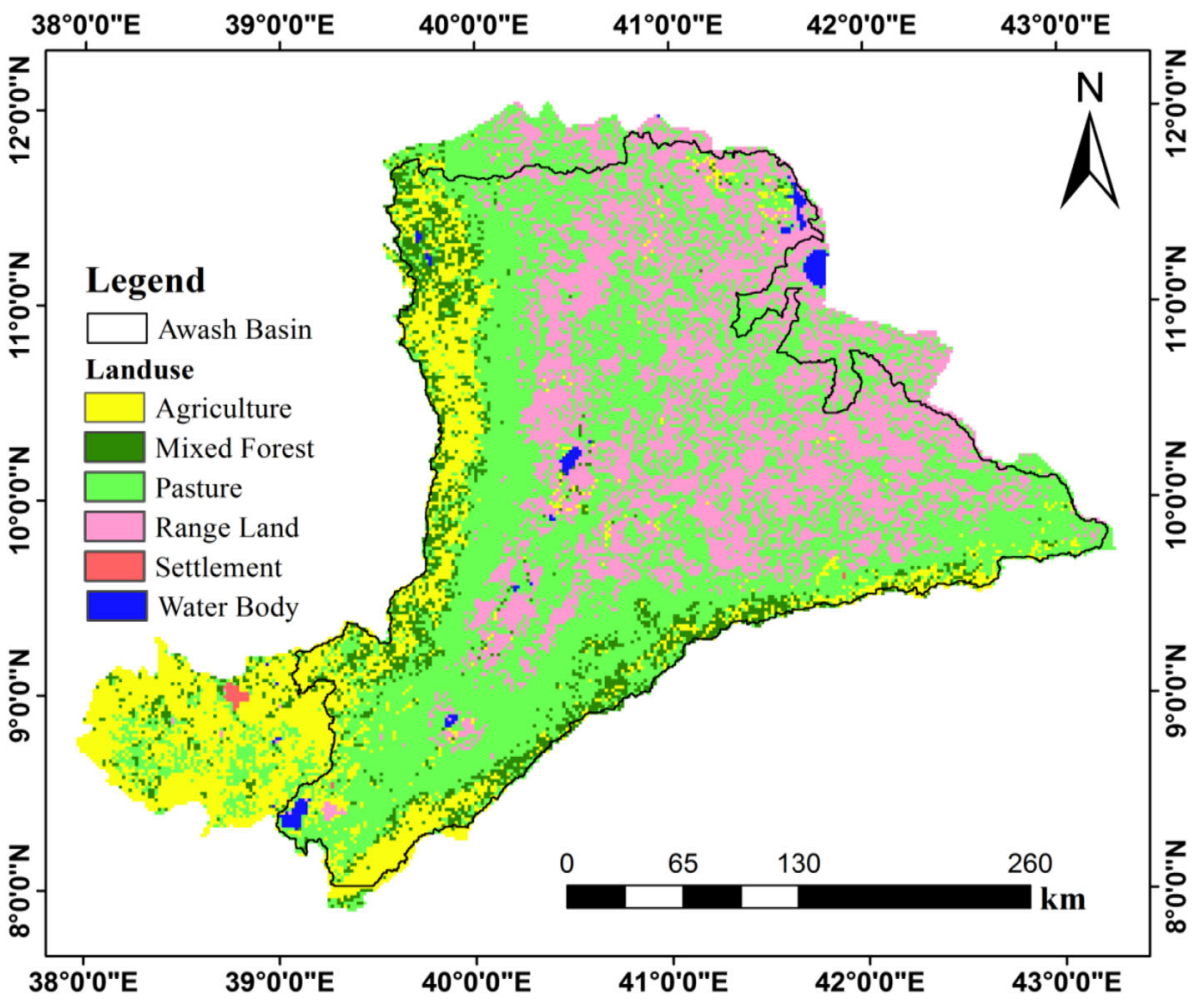

Table 3 Values of parameters ( $r$ - and $p$-) used for sensitivity and validation

\begin{tabular}{llrl}
\hline No. & Parameter name & $r$ value & $p$ value \\
\hline 1 & SOL_AWC & -2.61 & 0.011 \\
2 & ESCO & -2.11 & 0.038 \\
3 & RCHRG_DP & 1.76 & 0.082 \\
4 & GW_SPYLD & -1.74 & 0.087 \\
5 & GW_DELAY & 1.42 & 0.159 \\
6 & GWQMN & 0.55 & 0.584 \\
7 & GW_REVAP & -0.37 & 0.709 \\
8 & SUR_LAG & -0.26 & 0.795 \\
9 & ALPHA_BF & 0.92 & 0.362 \\
10 & SOL_BD & 0.87 & 0.388 \\
11 & OV_N & -0.84 & 0.405 \\
12 & CN2 & 0.60 & 0.500 \\
\hline
\end{tabular}

flow and hence results in decreased water yield, i.e. AWC is inversely related to water balance components. Evaporation compensation factor (ESCO) also affects the water balance components. The observed and predicted flow values are closer when ESCO values are near its maximum for the basin. This is the results of an increased base flow value and surface runoff for high values of the soil evaporation compensation factor. This study shows that the water balance components for the Awash basin are least sensitive to GW_SPYLD values i.e. a change in the initial
Table 4 Details of Model Simulation for the Basin

\begin{tabular}{|c|c|c|}
\hline S1. No. & Simulation details & Remark \\
\hline 1 & Simulation length & 33 years \\
\hline 2 & Warm up period & 3 years \\
\hline 3 & Calibration period & $\begin{array}{l}20 \text { years including } \\
\text { warm up period }\end{array}$ \\
\hline 4 & Validation period & 13 years \\
\hline 5 & Total number of subbasins & 70 \\
\hline 6 & $\begin{array}{l}\text { Total numbers of hydrologic } \\
\text { response units }\end{array}$ & 300 \\
\hline 7 & Input meteorological data & Measured \\
\hline 8 & Total basin area & $110,000 \mathrm{~km}^{2}$ \\
\hline
\end{tabular}

GW_SPYLD value will not greatly affect water balance components.

\section{Estimation of water yield of the basin}

Water scarcity in Awash basin is projected to increase over time due to increasing population, change in climate, land use and land cover. Water balance models such as SWAT can be used to assess the availability of water resources and the long-term influences of water management on the resources. This helps in planning mitigation measures against water scarcity that the future generation is inevitably going to face. The water yield of the basin when modelled by 
Table 5 Evaluation statistics of the basin at different stations

\begin{tabular}{|c|c|c|c|c|c|c|c|}
\hline \multirow[t]{2}{*}{ Years } & & \multirow[t]{2}{*}{ No. } & \multirow[t]{2}{*}{ Station name } & \multicolumn{4}{|c|}{ Evaluation statistic parameters } \\
\hline & & & & $R^{2}$ & NSE & PBIAS & RMSE \\
\hline \multirow[t]{8}{*}{ 1980-1999 } & Calibration & & & & & & \\
\hline & & 1 & Awash 7 kilo & 0.91 & 0.90 & 0.00 & 0.50 \\
\hline & & 2 & Below kkd & 0.86 & 0.83 & 66.00 & -2.64 \\
\hline & & 3 & Keleta sire & 0.89 & 0.89 & 7.37 & 8.00 \\
\hline & & 4 & KsemHm & 0.92 & 0.87 & -7.12 & 69.20 \\
\hline & & 5 & Melkasedi & 0.90 & 0.89 & -4.39 & 71.53 \\
\hline & & 6 & Metehara & 0.92 & 0.77 & 2.94 & 41.92 \\
\hline & & 7 & Wonji & 0.78 & 0.75 & 18.5 & 34.94 \\
\hline \multirow[t]{7}{*}{ 2000-2012 } & Validation & 1 & Awash 7 kilo & 0.81 & 0.78 & 12.0 & 81.00 \\
\hline & & 2 & Below kkd & 0.84 & 0.81 & -2.5 & 143.00 \\
\hline & & 3 & Keleta sire & 0.82 & 0.80 & 14.46 & 9.21 \\
\hline & & 4 & KsemHm & 0.95 & 0.93 & -5.19 & 53.18 \\
\hline & & 5 & Melkasedi & 0.89 & 0.87 & -7.85 & 75.13 \\
\hline & & 6 & Metehara & 0.84 & 0.73 & 9.98 & 40.85 \\
\hline & & 7 & Wonji & 0.57 & 0.55 & 14.05 & 99.06 \\
\hline
\end{tabular}

high level of human development (Jonathan 2000). Considering a minimum per capita water availability of $145 \mathrm{l} /$ c/day for urban population and $45 \mathrm{l} / \mathrm{c} /$ day for rural population, the total domestic water requirement of the basin will be $0.326 \mathrm{BCM} / \mathrm{year}$.

\section{Irrigation water demand}

The crop water need (ET crop) is the depth or the amount of water needed to meet the water loss through evapotranspiration. It depends on climate (sunshine, temperature, humidity, and wind speed), crop type and the growth stage of the crop. The influence of the climate on crop water needs is given by the reference crop evapo-transpiration, ETO (FAO Water 2012). Due to time constraint to collect all relevant data required to estimate water requirement for irrigation, previous study results were adapted. Yibeltal et al. (2013) made a comprehensive irrigation assessment in the basin and found out that the agricultural water requirement of the basin is estimated at $2.52 \mathrm{BCM}$ for 2012 cropping pattern.

\section{Livestock water demand}

Providing good quality water is essential for healthy livestock husbandry. The daily water requirement of livestock varies significantly among animal species (Table 7). The animal's size and growth stage will have a strong influence on daily water intake. Consumption rates can also be affected by environmental and management factors. Feed with relatively high moisture content decreases the quantity of drinking water required (Taddese et al. 2001). 


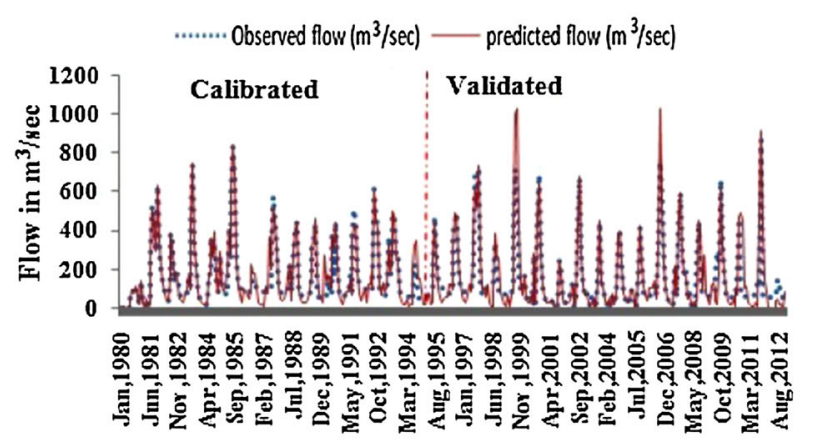

(a) Below KKd

Time in Years

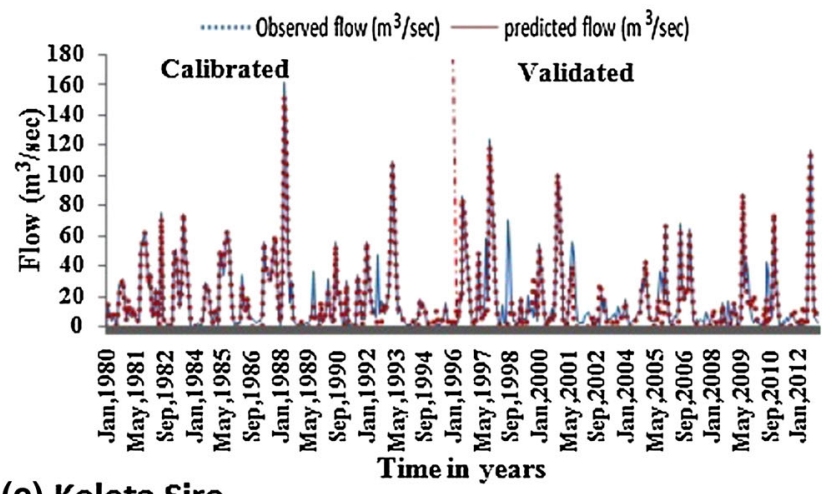

(c) Keleta Sire

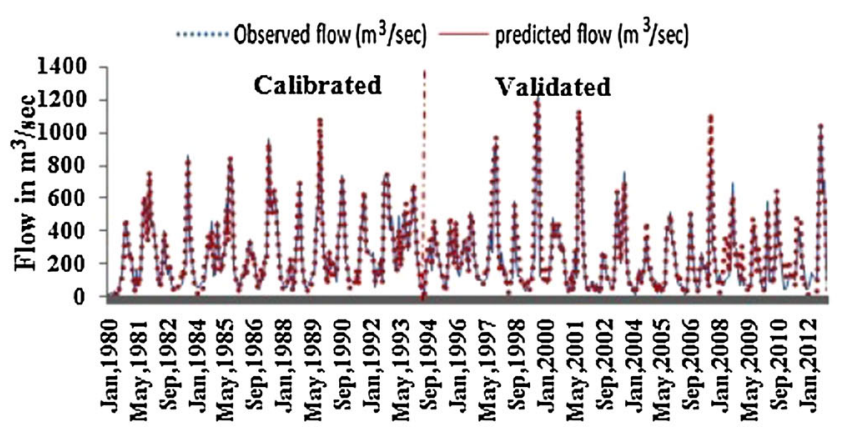

(e) Melka Sedi
Time in years

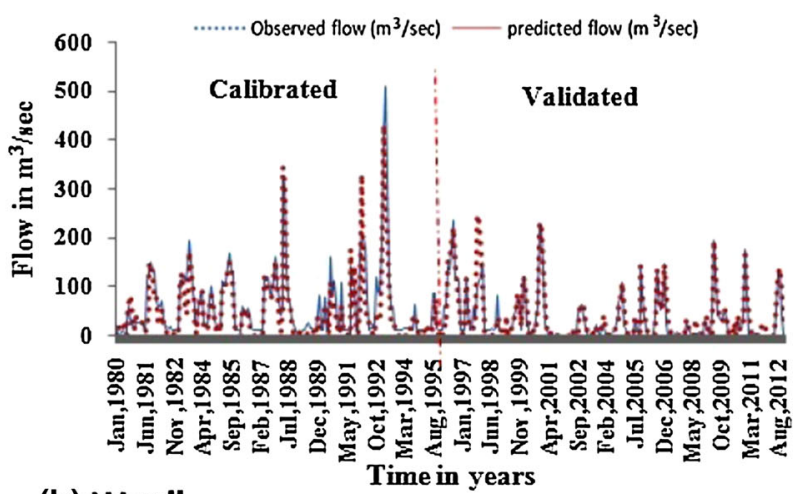

(b) Wonji
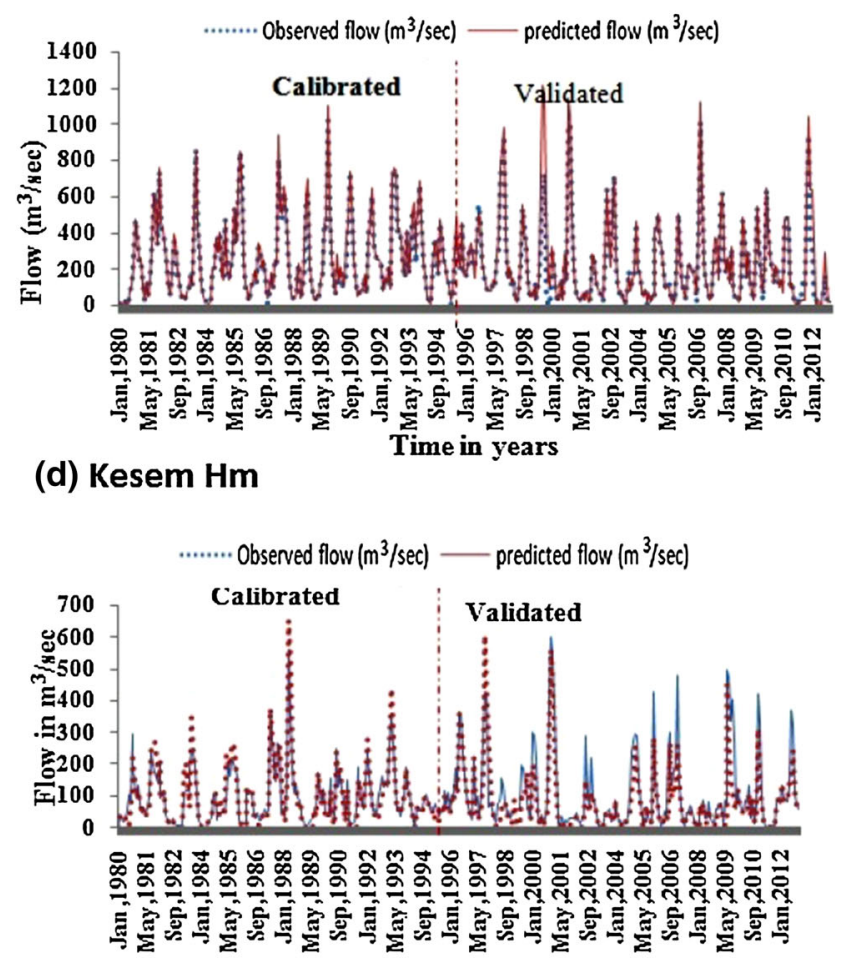

(f) Metehara
Time in Years

Fig. 7 Calibration and validation of flow data of the basin at different stations

\section{Industrial water requirement}

Industries that produce metals, paper, pharmaceuticals, chemicals, liquor, textiles and others all use water in their production process. It depends on water for all levels of production. Data on industrial water use are difficult to get because most of them use their own water sources. Water for industry use is not registered by municipality. For Addis Ababa alone, the estimate of these data is obtained from the Addis Ababa water supply and sewerage agency. The estimate of water use for industries in and around Addis Ababa is about $8 \%$ of the total daily domestic water requirement of the city. This is equivalent to approx.
$16,800 \mathrm{~m}^{3} /$ day and $0.00613 \mathrm{BCM} / \mathrm{year}$ for Addis Ababa and its surrounding. For industries outside Addis Ababa but located in the basin, it is assumed that their water requirement is about $0.001 \%$ of the basin yield which is equivalent to $0.00464 \mathrm{BCM}$. Therefore, the total industrial water requirement in the basin is estimated at 0.01084 BCM.

\section{Environmental water requirement}

The specification of an environmental water requirement varies depending on the objective of environmental water management. It can be a complex and its estimation should 
Table 6 Parameters Used in the calibration and validation of the model

\begin{tabular}{llll}
\hline No & Name & Value range & Fitted value \\
\hline 1 & SOL_AWC & $0-1$ & 0.05 \\
2 & CN2 & $35-98$ & 65 \\
3 & ALPHA_BF & $0-1$ & 0.1 \\
4 & GW_DELAY & $0-500$ & 12 \\
5 & REVAP_MN & $0-500$ & 0 \\
6 & OV_N & $0.01-30$ & 0.14 \\
7 & ESCO & $0-1$ & 0.95 \\
8 & GW_REVAP & $0.02-0.2$ & 0.2 \\
9 & SUR_LAG & $0.05-24$ & 8 \\
10 & USLE_K & $0-0.65$ & 0.3 \\
11 & SOL_BD & $0.9-2 \mathrm{O5}$ & 1.41 \\
12 & GW_SPYLD & $0-0.4$ & 0.03 \\
\hline
\end{tabular}

Table 7 Livestock population in the Basin and their Water Requirement

\begin{tabular}{llll}
\hline $\begin{array}{l}\text { Type of } \\
\text { animal in } \\
\text { the basin }\end{array}$ & $\begin{array}{l}\text { Livestock } \\
\text { population } \\
\text { (million) }\end{array}$ & $\begin{array}{l}\text { Average water } \\
\text { requirement } \\
\text { (L/day/head) }\end{array}$ & $\begin{array}{l}\text { Water } \\
\text { requirement } \\
\text { (BCM/year) }\end{array}$ \\
\hline Cattle & 5.42 & 54 & 0.10683 \\
Sheep/goat & 10 & 7.14 & 0.02606 \\
Equine & 0.65 & 45.6 & 0.01082 \\
Camel & 0.90 & 55 & 0.01807 \\
Poultry & 1.89 & 450 lt/1000 birds/day & 0.0031 \\
Total & & & 0.165 \\
\hline
\end{tabular}

be viewed in the context of natural variability of flow regimes (Poff et al. 1997). The most appropriate methodology depends on the individual case, including the specific objectives of the task, the amount of data and other available information. The total environmental water requirement consists of ecologically relevant low-flow and high-flow components (Smakhtin et al. 2004). There is seasonal flow variation in river basins depending on the rainfall. Up to 75 percent of the annual flow may come during rainy seasons in the basin. The river flows may reduce to a great extent during dry periods. It has been estimated that approximately $20-50$ percent of the mean annual river flow in different basins needs to be allocated to freshwater-dependent ecosystems to maintain a fair condition (Smakhtin et al. 2004). For Awash basin, the environmental flow requirement is estimated to be about 35 percent of the mean annual river flow i.e. 1.64 BCM/year.

\section{Water balance}

Water scarcity occurs when demand for water exceeds supply, and it can occur at any level of supply and demand.
The total annual surface water resources potential of Awash basin according to this study is estimated to be about 4.64 BCM. The average water demand in the basin is about $4.67 \mathrm{BCM}$. This shows on the average, the deficit of $0.03 \mathrm{BCM}$ of water in the basin. The seasonal deficit (intraannual shortage) of water is even more serious than inter annual deficit, because the precipitation falling on the land surface in the basin is highly variable in space and time, resulting in seasonal water surplus and shortage. June to September is the rainy months of the basin, during which availability of water exceeds demand. This has negative consequences on demand, because, it builds up water demand during the period. As a result, it leads to over-allocation of water which cannot be satisfied during lean season. Due to this hydrological variability and water management, water scarcity varies over time. The monthly deficit and surplus of water is shown in Fig. 8. During December-April month of 2011, the basin shows a deficit of $1.27 \mathrm{BCM}$, while there is an excess water of $1.67 \mathrm{BCM}$ during the months of May-November. In 2012, during the similar months, there is a deficit of $2.82 \mathrm{BCM}$, whereas there is a surplus of $3.16 \mathrm{BCM}$ of water during JuneNovember. The water scarcity in the basin is economic water scarcity (lack of water infrastructure, lack of investment in the sector, and lack of technical capacity) rather than physical water scarcity. The availability of water fluctuates from year to year and within a year. Therefore, if a storage structure is available, the surplus water can be stored for latter use and it can also serve the purpose of flood protection. In basins where water scarcity is a critical problem like in Awash basin, one of the options to control water supply to match demand is by providing storage reservoirs to capture floods during wet season. Storing water during the high-flow seasons and reallocating it during dry season can achieve potentially high benefits in the basin. It can reduce the gap between demand and supply to a large extent. Construction of high capacity dams to ensure yearly carryover capacity of close to $40 \%$ of the annual river flow can help in achieving water security during lean season. Construction of large dams in the basin has an advantage of reliable yield because evaporation is relatively less due to their depth. The location of the reservoir needs to be carefully chosen near the service point to avoid conveyance losses. One of the options/or way forward is to have reservoirs in the west and southwest of the basin because it is in this part of the basin that maximum rainfall occurs and then huge runoff is generated. The temperature of this part of the basin is also relatively low indicating less evaporation loss.

In calculating the water demand, the domestic, industrial and livestock water demand is distributed uniformly over the year for convenience. The agricultural water demand is distributed over 5 months (December-April), because 
these months are critically dry months when the crops require water. Then demand versus supply graph is plotted. The graph is plotted yearly for the validation period from 2000 to 2012 (Fig. 9), and for the last 2 years (2011 and 2012), it is plotted on monthly basis to show the deficit clearly. The flow chart for surface water assessment and demand estimation to calculate surface water balance is shown in (Fig. 10).

Agriculture is obviously the main water consumer. Irrigation efficiency in Ethiopia is low in the order of 30-40 percent (Yibeltal et al. 2013). A great deal of water can be saved by increasing the efficiency of irrigation and narrowing the gap between the stated policy and the actual practice regarding water resources management. The federal and/or regional level authorities should show an interest to enforce a law to keep control of an illegal abstraction of water. New small-scale irrigation schemes that are developed by individual farmers from time to time without planning can increase competition for water and thus create conflict between upstream and downstream users. So this expansion of small-scale irrigation should also be made on planning basis. The conflict between environment and agriculture in water demand, especially where almost total base flows are diverted for irrigation without releasing water for ecological conservation, should be examined and addressed.

Water can also be saved in industrial and urban water supply by rational use of water and recycling. Access to safe drinking water varies significantly among rural and urban areas. The water supply coverage for rural and urban is 41.2 and $78.8 \%$ (Ministry of Water, Irrigation and Energy of the Government of Ethiopia 2010; Ministry of Water Irrigation and Energy Resources 2010), respectively. Large quantities of water can be saved by reducing leakages from pipelines, taps and storage tanks. It is estimated that approximately $40 \%$ of domestic water supply is lost in distribution systems (Desalegn 2005).

\section{Impacts of water scarcity on sustainable development}

Water scarcity occurs as a result of climatic variability, increase in demand due to population growth which calls for increased allocation of water in the basin for different uses. Water poses a serious challenge to sustainable
Fig. 8 Monthly surface water balance of Awash basin

Fig. 9 Water balance for validation period (2000-2012)
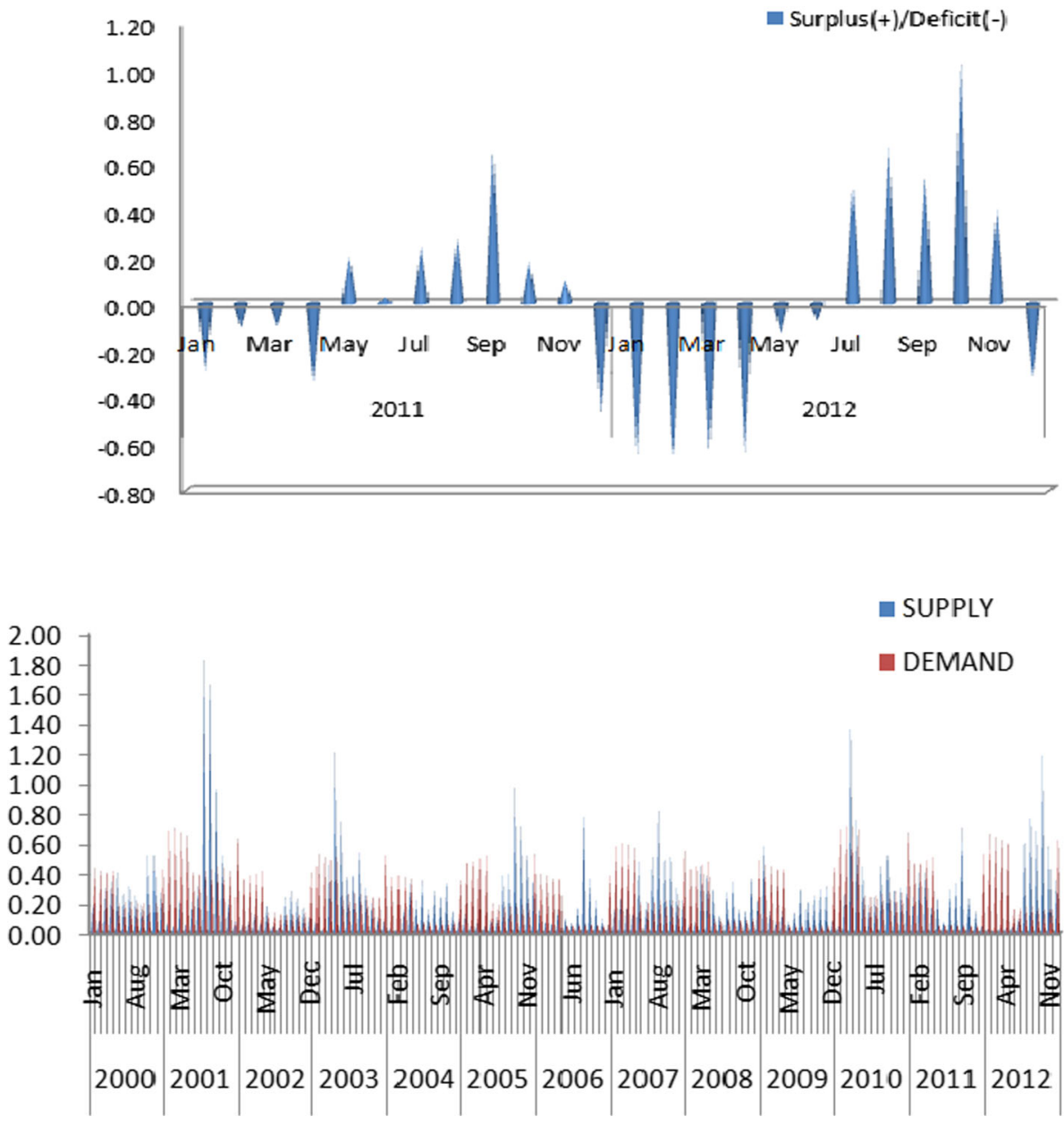
Fig. 10 Flow chart for water balance estimation

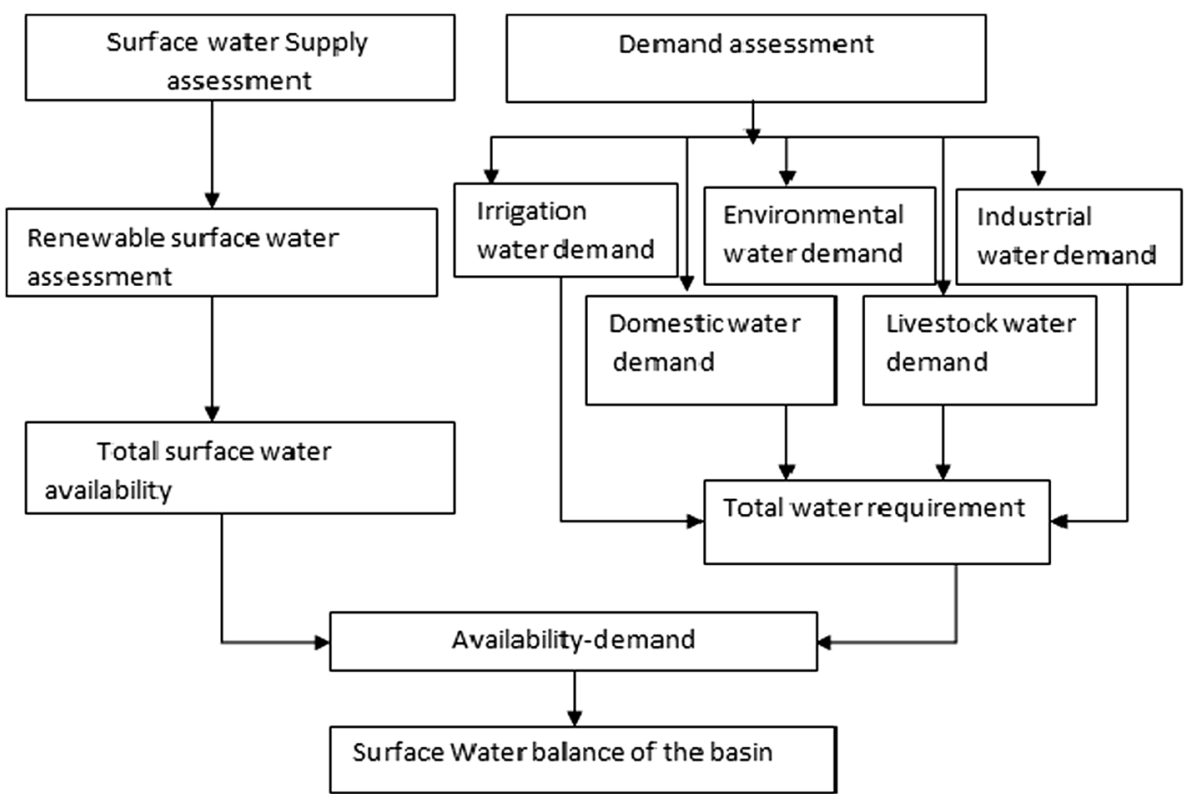

development. Its scarcity affects both social and economic sectors and threatens natural resources sustainability. Most of the communities living in the middle and downstream of the basin are pastoralists. Their livelihood entirely depends on animal husbandry. The availability of water is very crucial for these people and their animals. So they move from place to place in search of water and pasture specially during dry season. During drought which occurs frequently (once in every 5-10 years), they suffer a huge loss of animals and forced to depend on food aid from NGOs and Government. This usually impacted the country's economy and constrained development.

\section{Addressing water scarcity}

Water is an important resource for socio-economic development, the livelihood of the community in the basin and ecosystem health. Therefore, the equitable and wise use of water is important to guarantee water security and address the conflict arising among communities. Irrigated agriculture is the major user of water in the basin. In order to have a sustainable growth in Ethiopia, irrigation sector must use water judiciously. Further, misuse and overuse of water in all the other sectors such as industrial, domestic, and public should be avoided, because water is a finite resource and its future supply is uncertain in the basin unless water saving measures are taken. Water saving requires attention because the current situation in the basin reveals that the freshwater supply is hampering sustainable economic development. Huge amount of water can be saved either from irrigation sector and/or domestic and industrial water supply by substituting obsolete irrigation technologies with modern ones like sprinkler and drip irrigation that have the potential to increase water use efficiency from 30-40 to more than $75 \%$. Metering of water helps in water demand management. A customer whose water is metered uses less water than those whose water is not metered because he knows that he must pay for any misuse.

Inter-sectoral and multidisciplinary approach in alleviating water scarcity ensures mutual understanding of the existing problem. This brings about coordinated action in management of scarce water resources of the basin to maximize socioeconomic growth on a sustainable basis. Water supply sources can be improved by water harvesting; improving water efficiency in agriculture, and reducing an unaccountable loss in domestic water supply. Water scarcity alleviation can also be achieved by increasing the productivity of water use in every sector. The restoration and conservation of watershed, that stores and releases water, is important to increase water availability.

Seasonal water scarcity in the basin can be overcome by capturing the rainwater which occurs during a short rainy season and causes flooding. Rain occurs in the basin during June-September and creates huge flood damage in the downstream region of Afar. Storing the runoff generated during this season has dual advantage for the country. The first and foremost advantage is that it protects the lives of thousands of people from flood damage at the downstream. The other advantage is that the stored water can be used for different purposes in dry season when the demand for water is high.

The policy issue of the country in water resources management and uses should be reconsidered. The policy should be designed to increase water efficiency, to improve water yielding processes of the basin and to discourage overuse of water by different sectors to address scarcity. 
The issue of water pollution by industries and solid wastes needs immediate attention. This is the mandate of environmental protection authority of Ethiopia. But the rules and regulations regarding environmental quality is not practically followed and the authority is not taking any action when the rules are not adhered to by the industries. Therefore, following specific suggestions are made for addressing the water scarcity issues in Awash basin:

1. The study shows that availability of water in the basin cannot meet the current demand of water for different uses. This calls for improving water management and raising the level of awareness among the stakeholder about the gap between supply and demand of water in the basin. Decision makers should act vigorously to bring about equitable and rational use of water by different sectors so as to avoid overuse and wastage of water.

2. Stakeholder participation in all phases of water resources development should be given a weightage and should be encouraged. Water should be fairly shared among upstream and downstream users and between regions. The sectorial water use must be quantified, and all discharge measuring points should be renovated to know the volume of water abstracted for different purposes at different points.

3. Minimization of losses of water in irrigation and unaccounted losses in water supply systems is required. Irrigation efficiency should be improved by introducing current technologies to minimize/avoid water losses.

4. Water pollution standards should be established and enforced by law. Industries should treat their discharges to an acceptable level before letting it into water systems. The minimum allowable polluting substances to be let into water system should be fixed by a competent authority.

5. The price of water should discourage overuse of the resource and the costs of water supply should be recovered. Environmental and social impacts of water scarcity should be averted by improving the weak cross-sectorial integration which is involved in water management in one way or the other.

6. Loss of biodiversity and ecosystem service is brought about by degradation of water resources. So in order to avoid overuse of water and maximize the water use efficiency, water should be managed in an integrated way. Integrated water resources management should be designed in the basin to address the economic development combined with the needs of the environment to sustain development. This requires coordination among sectors, and replacement of fragmented resource management with coordinated and participatory process. Integrated water resources management framework should encompass ecosystem services that would enable the realization of a broad benefit from well-managed water and other related natural resources. This benefit may include both flood and drought mitigation, wildlife habitat conservation and the like. In integrated water resources management, the traditional top-down management approach should be supplemented by bottom-up approach. This is important in integrating and harmonizing various stakeholders' views and interest.

7. Environmental flow is the most important variable that impacts river morphology, aquatic habitat and water quality. The Awash basin river ecosystem is deteriorating significantly due to overuse of water for different purposes. Environmental flows which closely follow the natural flow regime are needed for ecosystem health (Jain 2012). The adverse impacts that result from water storage and/or diversion of river flows can be mitigated by releasing water to satisfy environmental water requirements. To achieve the desired balance of economic benefits and environmental costs, the fraction of mean annual flow (MAF) that can be abstracted/released should be decided depending on different factors like size of the river (Jain 2012). Awash river basin has a religious and cultural values attached to it. The Oromo people living in the basin exercise religious rituals called Irrecha. In view of this, $35 \%$ of the MAF of the river is allocated to the environmental flow to ensure that there is enough depth and discharge of good quality water in the river. This recommendation also helps rehabilitate/restore the current deteriorating floodplains and riparian vegetation of the basin. Once the current condition of the basin has been improved, the environmental flow requirement can be reduced to $8-10 \%$ of the mean annual flow to avail minimum water for people and basic survival of aquatic lives.

\section{Conclusions}

This study developed a surface water balance for Awash basin using SWAT model. Water balance studies can be used to assess the effect of anthropogenic activities and climate change on the volume of water that the basin can supply. It also helps establish the relationship between rainfall and runoff for forecasting purposes, the rational use of water and its redistribution in space and time. The annual water balance for Awash river basin was evaluated taking into account all the parameters that could be 
evaluated. The water balance calculation for the basin revealed that the basin is water deficit. The total surface water yield of the basin is estimated to be $4.64 \mathrm{BCM}$, while the total demand is about $4.67 \mathrm{BCM}$. This shows that there is a deficit of $0.03 \mathrm{BCM} / \mathrm{year}$ of surface water in the basin.

The seasonal water deficit is even very serious. The monthly deficit and surplus of water is calculated for the last 2 years of the study period. During December to April month of the year 2011, the basin shows a deficit of 1.27 BCM, while there is an excess water of $1.67 \mathrm{BCM}$ during the months of May to September. In 2012, during the similar months, there is a deficit of $2.82 \mathrm{BCM}$, whereas there is a surplus of $3.16 \mathrm{BCM}$ of water during June-October.

Addressing the challenges of water scarcity will require both selective development and exploitation of new water supplies and comprehensive policy reform that encourages more efficient use of existing water supplies. Exploitation of new water supply like harvesting rainwater and storing the excess flood during rainy period can alleviate water scarcity in the basin to a great extent. So the immediate future task of the decision makers should be to protect the ecology of the basin from further deterioration of the resources and exploit different sources of water to mitigate the current water scarcity.

Acknowledgments The authors are very grateful to editor of sustainable water management journal and two anonymous reviewers for their constructive comments on an earlier version of the manuscript that have enriched the contents of the paper. However, the views expressed here are those of the authors alone.

\section{References}

Abbaspour KC (2012) SWAT-CUP SWAT calibration and uncertainty programmes-A user manual. http://www.neprashtechnol ogy.ca/Downloads.aspx. Accessed 02 Oct 2014

Arnold JG, Fohrer N (2005) SWAT 2000 current capabilities and research opportunities in applied watershed modelling. Hydrol Process 19:565-572

Berhanu AT (2008) Water allocation study of upper awash valley for existing and future demands. MSc thesis, Addis Ababa University

Desalegn WB (2005) Water supply coverage and losses in distribution system the case of Addis Ababa. MSc thesis, International Institute for Geo-information Science and Earth observations, Enschede, The Netherlands

FAO (2012) Coping with water scarcity. An action framework for agriculture and food security, Food and Agriculture Organization of the United Nations, Rome, Italy. http://www.zaragoza.es/ ciudad/medioambiente/onu/en/detallePer_Onu?id=450. Accessed 25 Dec 2014

FAO Water (2012) Land and water division crop water information. http://www.fao.org/nr/water/cropinfo_cotton.html. Accessed 2 Feb 2015

Gassman PW, Reyes MR, Green CH, Arnold JG (2007) The soil and water assessment tool: historical development, application, and future research directions. Am Soc Agric Biol Eng 50:1211-1250
Gupta HV, Shian S, Yapo PO (1999) Status of automatic calibration for hydrologic models Comparison with multilevel expert calibration. J Hydrol Eng 4:135-143

Hassan MM, Croke BFW (2013) Filling gaps in daily rainfall data, a statistical approach. 20th international congress on modelling and simulation, Adelaide, Australia 1-6 December 2013

Jain SK (2012) Assessment of environmental flow requirements. Hydrol Process 26:3472-3476, Wiley online library (wileyonlinelibrary.com). doi:10.1002/hyp.9455

Jonathan C (2000) Centre for Environmental Strategy, University of Surrey, Guildford, Surrey, GU2 7XH, UK. Minimum water requirement for social and economic development. https://www. google.co.in/search?newwindow $=1 \&$ espv $=2 \& q=\% 2 \mathrm{C}+$ Centre + for+Environmental + Strategy $\% 2 \mathrm{C}+$ University + of + Surrey $\% 2 \mathrm{C}+$ Guildford $\% 2 \mathrm{C}+$ Surrey $\% 2 \mathrm{C}+\mathrm{GU} 2+7 \mathrm{XH} \% 2 \mathrm{C}$. Accessed 15 Jan 2015

Kannan N, White SM, Worrall F, Whelan MJ (2007) Sensitivity analysis and identification of the best evapo-transpiration and runoff options for hydrological modelling in SWAT 2000. J Hydrol 332:450-466

Kansal ML, Adeba D, Aditya T (2014) "Challenges of Sustainable Development and Management of Water Resources in Ethiopia" World Environmental \& Water Resources Congress, ASCE, June 1-5, 2014, Portland, Orlando, USA

Legates DR, McCabe GJ Jr (1999) Evaluating the use of "goodnessof-fit" measures in hydrologic and hydro-climatic model validation. Water Resour Res 35:233-241

Milivojevic N, Simic Z, Orlic A, Milivojevic V, Stojanovic B (2009) Parameter estimation and validation of the proposed SWAT based rainfall runoff model-methods and outcomes. J Serbian Soc Comput Mech 3:86-110

Ministry of Water, Irrigation and Energy of the Government of Ethiopia (2010) http://www.mowr.gov.et/index.php?pagenum= 2\&pagehgt $=1785$ px. Accessed $1 \mathrm{Feb} 2015$

Ministry of Water Irrigation and Energy Resources (2010) Awash river basin background. http://www.mowr.gov.et/index.php?pa genum=3.3\&pagehgt=1000px. Accessed 2 Feb 2015

Monteith JL (1965) Evaporation and the environment. In the state and movement of water in living organisms. 19th Simposia of the Society for the Experimental Biology. Cambridge University Press, London, pp 205-234

Moriasi DN, Arnold JG, Van Liews MW, Bingner RL, Harmel RD, Veith TI (2007) Model evaluation guidelines for systematic quantification of accuracy in watershed simulation. Trans Am Soc Agric Biol Eng 50(3):885-900

Nash JE, Sutcliffe JV (1970) River flow forecasting through conceptual models part $1-\mathrm{A}$ discussion of principles. J Hydrol 10:282-290

Neitsh SL, Arnold JG, Kiniry JR, Williams JR, King KW (2001) Soil and Water Assessment Tool (SWAT)-version 2000 Users manual. Temple, Texas

Neitsh SL, Arnold JG, Kiniry JR, Williams JR, King KW (2002) Soil and Water Assessment Tool theoretical documentation. Texas Water Resources Institute, College Station, p 458

Poff NL, Allan JD, Bain MB, Karr JR, Prestegaard KL, Richter BD, Sparks RE, Stromberg JC (1997) The natural flow regimes a paradigm for river conservation and restoration. Bioscience 47:769-784

Singh V, Bankar NK, Salunkhe SS, Beraand AK, Sharma JR (2013) Hydrological stream flow modelling on Tungabhadra catchment:parameterization and uncertainty analysis using SWAT CUP. Curr Sci 104:1187-1199

Smakhtin V, Revenga C, Döll P (2004) A pilot global assessment of environmental water requirements and scarcity. Water Int 29:307-317 
Taddese G, Peden D, Astatke A, Kai S (2001) Improving the management of livestock in Awash river basin: a challenge to Ethiopia. http://www.iwmi.cgiar.org/assessment/files/word/Work shops/ILRI-March/Presentations/Girma.pdf. Accessed 30 Jan 2015

Taddese G, Sonder K, Peden D (2012) The Water of the Awash River basin a future challenge to Ethiopia. International Livestock Research Institute (ILRI), a working paper. http://www.iwmi. cgiar.org/assessment/files/pdf/publications/WorkingPapers/Water ofAwasBasin.pdf. Accessed 18 Jan 2015

Van Rooijen D, Taddese G (2009) Urban sanitation and waste water treatment in Addis Ababa in the Awash basin, Ethiopia 34th
WEDC international conference, Addis Ababa, Ethiopia, 2009 Water, Sanitation and Hygiene Sustainable Development and Multi-sectoral approach

Water Works Design and Supervision Enterprise (WWDSE)/WAPCOS (2005) Tendaho Dam and Irrigation Project, Crop water requirement for Sugar Cane, MoWR, Government of Ethiopia

Yibeltal T, Belte B, Semu A, Imeru T, Yohannes T (2013) Coping with water scarcity, the role of agriculture, developing a water audit for Awash river basin synthesis report GCP/INT/072/ITA Addis Ababa Ethiopia Dec 2013 